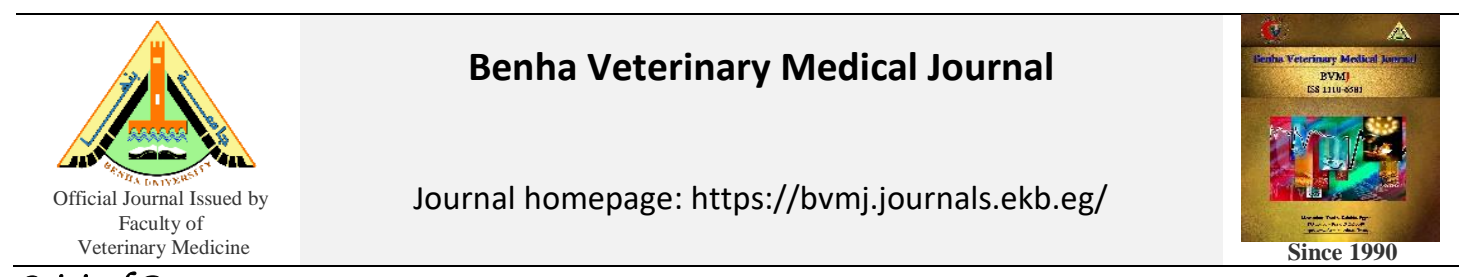

Original Paper

\title{
Prevalence of Clostridium perfringens infection and virulence genes detection in broiler chickens
}

\author{
Ashraf A. Abd El-Tawab', Amira M. Rizk' ${ }^{1}$, Mohammed M. El-Bardisy ${ }^{2}$, Shreen Mayouf ${ }^{3}$ \\ ${ }^{1}$ Bacteriology, Immunology and Mycology Department, Faculty of Veterinary Medicine, Benha University, Egypt. \\ ${ }^{2}$ Animal Health Research Institute, Dokki Giza, Egypt. \\ ${ }^{3} A$ Veterinarian, Al-Sharqia, Egypt.
}

\begin{tabular}{|c|c|}
\hline ARTICLE INFO & ABSTRACT \\
\hline $\begin{array}{l}\text { Keywords } \\
\text { Broiler chickens } \\
\text { C. perfringens } \\
\text { cpa gene } \\
\text { net B gene } \\
\\
\text { Received } 07 / 02 / 2019 \\
\text { Accepted } 19 / 03 / 2019 \\
\text { Available On-Line } \\
\text { 18/07/2020 }\end{array}$ & $\begin{array}{l}\text { Clostridium perfringens (C. perfringens) produces toxins that cause necrotic enteritis in broiler } \\
\text { chickens resulting in sever losses in poultry industry. This study aimed to investigate the } \\
\text { prevalence of } C \text {. perfringens in broiler chickens in Toukh, Qaliubiya governorate, Egypt. A } \\
\text { total of } 100 \text { broilers }(10-40 \text { days old) were collected from Toukh, Qaliubiya in } 2017 \text {. The } \\
\text { samples were collected from liver and intestine of both diseased and apparently healthy } \\
\text { broilers. All samples were subjected to bacteriological examination. C. perfringens was } \\
\text { isolated from ( } 70 \%) \text { and }(22 \%) \text { of diseased and apparently healthy broilers, respectively. The } \\
\text { isolates were typed by dermo-necrotic test in Guinea pig and PCR. The results of dermonecrotic } \\
\text { test from diseased chickens showed that } 40(65.6 \%) \text { of the isolates from diseased chickens were } \\
\text { type A and } 8(13.1 \%) \text { were type D. But the isolates from the apparently healthy chickens were } \\
\text { (9) type A and (6) type D. Typing of the nine } C \text {. perfringens isolates (from diseased broilers) } \\
\text { by PCR for toxin associated genes (cpa, cpb and etx) showed that } 8 \text { strains were positive for } \\
\text { cpa gene (typed as type A). Detection of the virulence genes by PCR showed, pfoS and colA } \\
\text { genes were in eight isolates but netB gene was detected in three isolates only. } C \text {. perfringens } \\
\text { showed high prevalence among diseased broiler chickens with high isolation rate from } \\
\text { intestinal sample than hepatic samples. Moreover, high percentage of } C \text {. perfringens is } \\
\text { toxigenic type A in case of diseased or apparently healthy broiler chickens. The netB gene } \\
\text { seems to be unnecessary for inducing necrotic enteritis in broiler chickens. }\end{array}$ \\
\hline
\end{tabular}

\section{INTRODUCTION}

Clostridium perfringens (C. perfringens) is a gram positive rod-shaped, anaerobic, spore-forming bacterium of the genus Clostridium. Necrotic enteritis (NE) caused by $C$. perfringens type $\mathrm{A}, \mathrm{C}$ and $\mathrm{D}$. NE is an enterotoxaemia of poultry which lead to an important economic losses in poultry production. This economic effect is due to decrease growth rate, feed conversion and increase condemnation rates in broiler due to hepatitis (Van immerseel et al., 2004). C. perfringens present in intestinal tract and produces a toxin leads to necrotic enteritis. Although, small number of organisms are found in the intestinal tract, they don't cause disease under normal condition as it is overcome by a considerable population of "good bacteria" (Vijay and Clerk, 2007).

C. perfringens could cause impaired production performance in chicken. The intestinal function is to achieve optimal feed conversion. There are some factors that reduce feed conversion as the necrotic gut lesion and abnormal clostridium dominance in gut micro flora together with clostridium toxin all this reduced productivity (Lovland and Kaldhusdal, 2001).

Immunosuppression predisposes animals to NEimmunosuppression likely alter the intestinal environment and the intestinal microbial population (Timberment et al., 2011).

Necrotic enteritis prevention is usually associated with management practices that minimize the effects of the predisposing factors that contribute to disease development. Reducing the inclusion of dietary ingredients that may lead to NE such as fish meal, oats, barley and rye has been acknowledged as natural solution in decreasing NE (Cooper and Songer, 2009).

Clinical necrotic enteritis occurs when $C$. perfringens proliferates to high number in the small intestine and produce extracellular toxins which damage the intestine (Keyburn et al., 2006). The major toxin believed to be involved is the alpha toxin, but its important role in the disease process is not completely understood.

The sings of necrotic enteritis in chicken are inappetence, marked depression with grayish diarrhea, unable to walk, voiding dually brownish to bloody stained diarrhea in well fleshed and nourished older broiler chicken and ruffled feather. On postmortem examination the lesions are restricted enteritis in small intestine of different degree. Intestine is ballooned with thickened wall. Necrosis in intestinal mucosa. The intestinal lumen filled with bloody stained ingest or blood (darkly stained) in severe cases. Liver is congested with areas of whitish to hemorrhagic necrosis and distended gall bladder (Ehab, 2007).

\footnotetext{
*Corresponding author: Amira Mohamed Rizkdr_az80@yahoo.com, dramz2001@gmail.com.
} 
Clostridium perfringens strains are classified into five types (A-E) on the basis of their ability to produce major lethal toxins. All types of $C$. perfringens produce alpha toxin. In addition, type $\mathrm{B}$ produces beta and epsilon toxin, type $\mathrm{C}$ produces beta toxin, type $\mathrm{D}$ isolates produce epsilon toxin and type E produces iota toxin (Hatheway, 1990).

The pathogenicity of $C$. perfringens is associated with several toxins; alpha, beta and epsilon toxins are the major toxic substances produced by the organism. These toxins encoded by $c p a, c p b$ and $e t x$ genes, respectively. Genotyping of $C$. perfringens is done by using specific primers in PCR for detection of toxin genes ( $c p a, c p b$, etx). This method is a powerful, rapid and confirmatory technique for typing of $C$. perfringens isolates.

Before the net $\mathrm{B}$ toxin was identified as the major toxin in necrotic enteritis in broiler, alpha toxin was believed to be crucial and thus multiple studies used alpha toxin derivatives as vaccine antigen.

The aim of the present study was to verify the prevalence of $C$. perfringens causing necrotic enteritis in broiler chickens and to study the toxin type of $C$. perfringens isolates with special reference to the virulence genes.

\section{MATERIAL AND METHODS}

\subsection{Sampling:}

A total of 100 broilers (10-40 days old) were collected from Toukh, Qaliubiya in 2017, of which (50) were sufferings from diarrhea and (50) were apparently healthy. The samples were collected from liver and intestine of both diseased and apparently healthy broilers. The collected 200 samples were kept under sterile conditions and were brought to the laboratory in an ice box without delay for bacteriological examination.

\subsection{Isolation and identification of $C$. perfringens}

Each sample was inoculated separately in cooked meat broth (Oxoid) and incubated anaerobically at $37{ }^{\circ} \mathrm{C}$ for $24 \mathrm{hrs}$ (Quinn et al., 2002). A loopful from the broth culture was streaked directly onto $200 \mathrm{mg} / \mathrm{ml}$ neomycin sulphate sheep blood agar plates (Oxoid) and incubated anaerobically
(Carter and Cole, 1990). The isolated colonies were identified by the cultural, morphological and biochemical characters (lecithinase, Catalase, indol, gelatin liquefaction and sugar fermentation test (Koneman et al., 1992; Macfaddin, 2002).

\subsection{Typing of C. Perfringens isolates:}

Clostridium perfringens isolates $(\mathrm{n}=70)$ from diseased broiler were typed by two different methods. Sixty-one isolates were typed by the dermonecrotic test in Guienea pig (G. pig) and nine randomly isolates were typed by PCR (Genotyping).

All the isolates $(\mathrm{n}=22)$ from apparently healthy broiler were typed by the dermo-necrotic test in G. pig (Quinn et al., 2002).

\subsection{Clostridium perfringens typing with detection of some virulence genes by PCR:}

Genomic DNA was extracted from isolated strains using QIAamp DNA Mini Kit (Cat. No. 51304, Qiagen). PCR amplification of the genomic DNA was performed using Emerald Amp GT PCR master-mix (Takara) Code No.RR310A. Briefly, PCR program was done by initial denaturation at $94{ }^{\circ} \mathrm{C}$ for $2 \mathrm{~min}, 35$ cycle of denature at 94 ${ }^{\circ} \mathrm{C}$ for $15 \mathrm{sec}$. annealing $\left(55^{\circ} \mathrm{C}\right.$ for $\mathrm{colA}$ and $-52^{\circ} \mathrm{C}$ for $\left.p f o \mathrm{~S}\right)$ for $30 \mathrm{sec}$. and final extension at $68{ }^{\circ} \mathrm{C}$ for $1 \mathrm{~min}$. The primers used in the PCR are shown in table (1). PCR products were separated by electrophoresis in $1.5 \%$ agarose gel. Bands were visualized by ethidium bromide staining (Sambrook et al., 1989)

\subsection{Antibiotic sensitivity test:}

C. perfringens isolates (from diseased broilers) were tested for their resistance to the following 15 antibiotics (Oxoid); amoxicillin (AMC) $30 \mu \mathrm{g}$, ampicillin (AMP) $10 \mu \mathrm{g}$, ampiclox (AX) $30 \mu \mathrm{g}$, penicillin (P) $10 \mu \mathrm{g}$, cefadroxil (CDX) $30 \mu \mathrm{g}$, streptomycin (S) $10 \mu \mathrm{g}$, tetracycline (TE) $30 \mu \mathrm{g}$, cloxacillin (CX) $1 \mu \mathrm{g}$, mupirocin (MUP) $5 \mu \mathrm{g}$, cefprime (FEP) $30 \mu \mathrm{g}$, cefrodoxim (CRD) $30 \mu \mathrm{g}$, erythrocine (E) 15 $\mu \mathrm{g}$,oxytetracycline (OT) $30 \mu \mathrm{g}$, max fur (EFT) $30 \mu \mathrm{g}$ and epicoflocin (OFX) $5 \mu \mathrm{g}$. The degree of sensitivity was interpreted according to NCCLS (2002) and NCCLS (2004).

Table 1 The PCR primers used for detection of virulence genes and toxin genes of $C$. perfringens

\begin{tabular}{|c|c|c|c|c|}
\hline Target genes & & Primer Sequence5'-3' & Reference & Amplicon size bp \\
\hline \multirow{3}{*}{ Virulence genes Uniplex PCR } & colA & $\begin{array}{l}\text { F-TAG GAA CAA AGG CGC AAG AT } \\
\text { R-TTC TCC TTG TCC CCA CAT TC }\end{array}$ & \multirow[b]{3}{*}{ Anthony et al., 2010} & 924 \\
\hline & $p f o S$ & $\begin{array}{l}\text { F-CGG GTA TAG GCA TAC AAA AGG A } \\
\text { R-GTG CAG TTG CAA CCA CTG TT }\end{array}$ & & 1090 \\
\hline & $n e t \mathrm{~B}$ & F-GCTGGTGCTGGAATAAATGC RTCGCCATTGAGTAGTTTCCC & & 383 \\
\hline \multirow{3}{*}{ Genotyping genes Multi-plex PCR } & cpa & $\begin{array}{l}\text { F-GCTAATGTTACTGCCGTTGA } \\
\text { R-CCTCTGATACATCGTGAAG }\end{array}$ & \multirow[t]{2}{*}{ Yoo et al.,1997 } & 324 \\
\hline & $c p b$ & $\begin{array}{l}\text { F-GCGAATATGCTGAATCATCTA } \\
\text { R-GCAGGAACATTAGTATATCTTC }\end{array}$ & & 196 \\
\hline & $e t x$ & $\begin{array}{l}\text { F-GCGGTGATATCCATCTATTC } \\
\text { R-CCACTTACTTGTCCTACTAAC }\end{array}$ & Yoo et al., 1997 & 665 \\
\hline
\end{tabular}

\section{RESULTS}

3.1. Isolation and identification of $C$. perfringens The isolated colonies showed a gram-positive anaerobic rods, sporulated, catalase negative, characterized by double zone of haemolysis on blood agar surrounding the colonies and cause stormy fermentation reaction in litmus milk media indicating $C$. perfringens.
3.2. Prevalence of $C$. perfringens in broiler chickens: Out of 100 samples from diseased broiler (50 intestines and 50 livers), 70 C. perfringens (42 from intestine, 28 from liver) were isolated with prevalence $(70 \%)$. Out of 100 samples from apparently healthy broilers (50 intestines and 50 livers), 22 C. perfringens (12 from intestine, 10 from liver) were isolated with prevalence $(22 \%)$. 
3.3. Lecithinase activity of $C$. perfringens isolates from diseased and apparently healthy broiler:

Lecithinase activity was detected in 56 out of $70 \mathrm{C}$. perfringens $(80 \%)$ isolates from diseased broiler characterized by an opalescence surrounding the colonies which inhibited by $C$. perfringens type A antitoxic sera. Lecithinase activity was detected in 14 out of $22 C$. perfringens isolates (63.6\%) from apparently healthy broiler.

\subsection{Typing by the dermonecrotic test:}

Typing of (61) isolates from diseased broiler using intradermal inoculation test in G. pig showed that 40 isolates (65.6\%) were of type A and 8 isolates (13.1\%) were of type D. On the other hand, typing of (22) C. perfringens isolates from apparently healthy broiler showed that 9 isolates were of type A and 6 isolates were type D (40.9\% and $21.3 \%$, respectively). Non-toxigenic strain were $13(21.3 \%)$ and $7(21.8 \%)$ for diseased and apparently healthy broiler, respectively.

3.5. Typing of $C$. perfringens isolates using PCR (Genotyping):

Typing of nine $C$. perfringens isolates (diseased broilers) by multiplex PCR for alpha, beta and epsilon toxin genes (cpa ,$c p b$, etx) showed that eight isolates were positive only for cpa gene. This indicated that eight isolates were $C$. perfringens type A (fig.1).

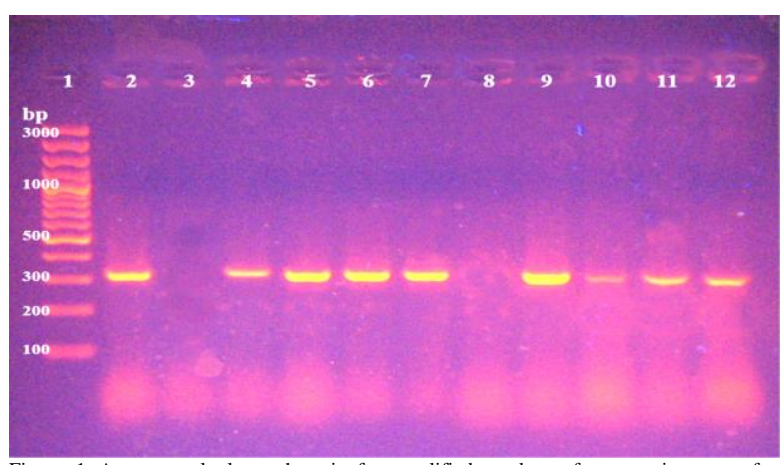

Figure 1 Agarose gel electrophoresis for amplified product of cpa toxin gene of C.perfringens isolates. Lane 1: 100 bp DNA ladder. Lane 2: control positive. Lane 3 control negative. Lane (4-7 \& 9-12) : positive isolates for cpa gene which amplified at 324 bp. Lane 8: negative for cpa gene.

3.6. Detection of the virulence genes in $C$. perfringens isolates by PCR :

Out of the nine isolates of C. perfringens (diseased broilers), pfoS and colA genes were detected in eight isolates while $n e t \mathrm{~B}$ virulence gene was positive in three isolates only as shown in Fig. $(2,3,4)$

\subsection{Antibiotic sensitivity test:}

Antibiotic sensitivity test revealed $C$. perfringens isolates were highly sensitivity to amoxicillin $(89.6 \%)$ followed by ampicillin and cefadroxyl (87.5\%) for each and ampiclox $(81.3 \%)$. Moderate sensitivity was noticed to penicillin and mupirocin $(77.1 \%)$ for each and cefeprim (72.9\%).The lowest sensitivity of the isolates was to maxfur $(63.5 \%)$ and epicoflocin (58.3\%). On the other hand, all isolates were (100\%) resistant to cloxacillin, streptomycin, tetracycline, oxy tetracycline, erythrocine and cefrodoxim

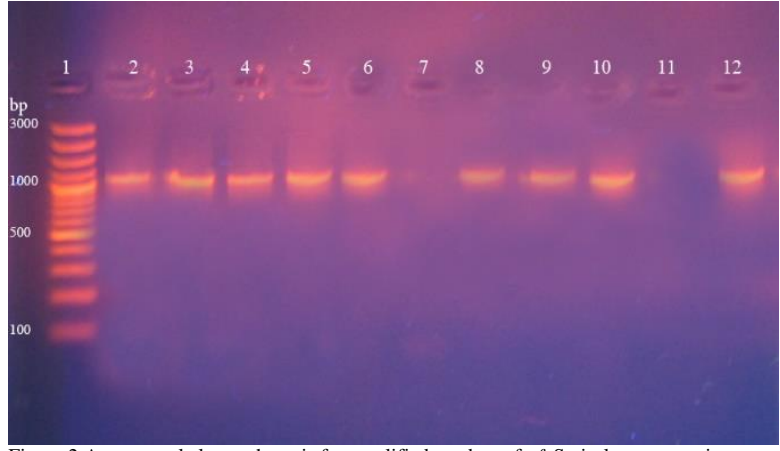

Figure 2 Agarose gel electrophoresis for amplified product of $p f o S$ virulence genes in C.perfringens isolates. Lane1:100 bp DNA ladder. Lane (2-6\& 8-10) positive isolates for $p f o \mathrm{~S}$ gene which amplified at $1090 \mathrm{bp}$. Lane 7: negative for $p f o \mathrm{~S}$ gene. Lane 11: control negative. Lane 12: control positive.

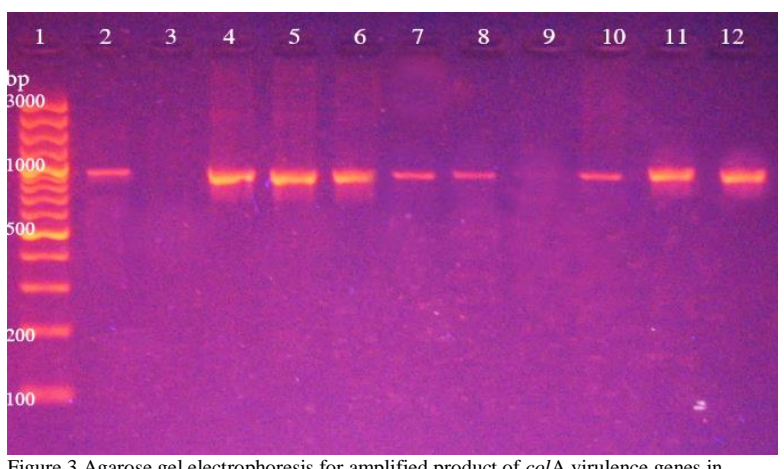

Figure 3 Agarose gel electrophoresis for amplified product of colA virulence genes in control negative. Lane (4-8\&10-12): positive isolates for colA gene which amplified at 924 bp. Lane 9: negative for colA gene.

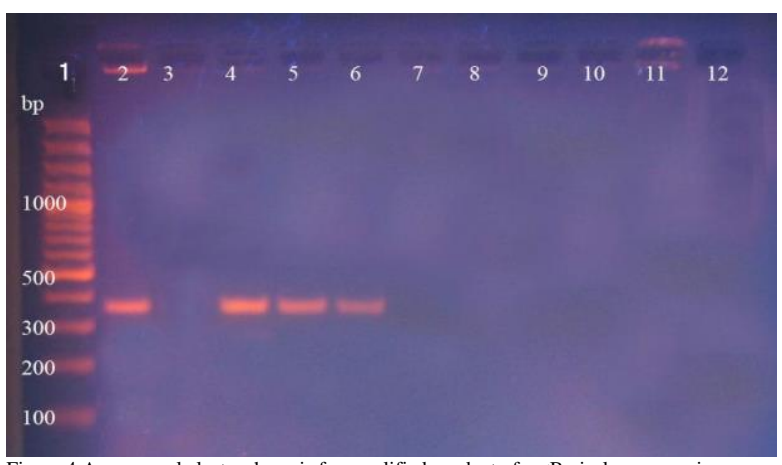

Figure 4 Agarose gel electrophoresis for amplified product of $n e t \mathrm{~B}$ virulence gene in C.perfringens isolates. Lane 1: 100 bp DNA ladder. Lane 2: Control positive. Lane 3: Control negative. Lane (4-6): positive isolates for net $\mathrm{B}$ gene which amplified at $383 \mathrm{bp}$. Lane (7-12): negative for net $\mathrm{B}$ gene.

\section{DISCUSSION}

Worldwide, NE is a serious disease affects poultry caused by $C$. perfringens and leads to production losses through increasing feed consumption and mortality rates and reducing broiler chicken welfare (Adhikari et al., 2020). Acute $\mathrm{NE}$ is characterized by a sudden increase in mortality without clinical signs. Meanwhile, the subclinical form is becoming more prevalent and is characterized by intestinal mucosal damage, decreasing nutrient digestion, absorption and feed conversion rate.In the current study, the $C$. perfringens prevalence among diseased broiler chickens was $70 \%$. 
This result is in accordance with previous results showed prevalence of $78 \%$ in NE affected broilers (Shane et al., 1984), $77.3 \%$ in broiler aged 1-15 week (Das et al., 2001) and $80 \%$ in poultry farms suffered from enteritis (Tschir et al., 1992). However, a lower $C$. perfringens prevalence of (48.5\%) has been reported by Abd El-salam (2000).

In the present study, the intestinal samples from diseased broiler showed a higher $(84 \%)$ isolation rate than hepatic samples with $(56 \%)$ isolation rate. This higher isolation rate from intestinal sample than that from hepatic samples is in line with previous results showed that $C$. perfringens isolation rate from intestine and liver was $47.4 \%$ and $12.3 \%$, respectively (Amal, 2012). Previous study reported lower $C$. perfringens isolation rate of $56 \%$ from balady chicken aged 4-8 weeks suffering from enteritis (Ahmed and Abd El-latif, 2004), 50\% of intestinal samples from broiler chickens with sever haemorrhagic enteritis (Ismail, 2002). This lower isolation rate compared to our results may be attributed to difference in the management practice and/or the use of different feed mixture. Indeed, the addition of fishmeal in the diet was described to alter the gut microbiota profile (Stanley et al., 2014), providing high nutrient levels for $C$. perfringens growth (Drew et al., 2004).

The current results showed that apparently healthy broiler harbored C. perfringens much lower than diseased broiler as isolation rate of $C$. perfringens was $24 \%$ and $20 \%$ from apparently healthy intestinal sample and liver sample, respectively. The tendency of higher isolation rate from intestinal sample than that from hepatic sample is similar albeit much lower than that recovered from diseased broiler. In the current results, typing of (70) $C$. perfringens isolates from diseased broiler by the intradermal inoculation test in Guinea Pig and PCR revealed that $80 \%$ were toxigenic. Out of this toxigenic isolates $85.7 \%$ belonged to type A while $14.3 \%$ belonged to type D. On the other hand of the toxigenic 15 isolates recovered from apparently healthy broilers were $60 \%$ belonged to type A and $40 \%$ belong to type $\mathrm{D}$. These results are in accordance with that reported by Abd-El-Tawab (2002), who isolated C. perfringens type "A", type "C" and type "D" from diseased geese with incidence of (73\%), (6.7\%) and (20\%), respectively. However, the current results are higher than that of a previous study reported that about $20 \%$ were Type A, $5 \%$ of each of Type D and C (Latino Vic, 1983).

$C$. perfringens type $\mathrm{C}$ was not detected in the present study in a disagreement with the finding of Sarakbi (1991), who reported that $C$. perfringens types $\mathrm{C}$ and $\mathrm{A}$ being the main cause of necrotic enteritis in broiler. A recent study reported that $C$. perfringens types $\mathrm{A}$ and $\mathrm{C}$ were the main etiological agents of necrotic enteritis in chicken (Diego and Andrey, 2014). However, $C$. perfringens type A was the majority (96\%) in isolates from chickens and turkey (Archambanlt, 2009). Moreover, C. perfringens type A was the only type of isolates from different sources including poultry (Johansson, 2006). Furthermore, C. perfringens types A was the only type identified in $75 \%$ of the isolates from chicken slaughtered for human consumption (Hakan and Hasan, 2005). This result augment our results that $C$. perfringens type A being the major cause of NE

In the present study the presence of $n e t \mathrm{~B}$ in only 3 isolates out of 9 type A isolates form diseased broiler may indicate the unnecessary presence of $n e t \mathrm{~B}$ for induction of the NE in broiler chickens. This assumption may contradict a previous proposal suggesting the presence of net $\mathrm{B}$ as a main factor for
C. perfringens to induce $\mathrm{NE}$ in chickens (Keyburn et al., 2008 \& 2010; Smyth and Martin, 2010). However, in accordance with the results of this study, a minority of $C$. perfringens strains isolated from clear cases of necrotic enteritis in chicken were reported to lack the net $\mathrm{B}$ gene (Chalmers, 2008; Keyburn, 2008).

In this study, Antibiotic sensitivity test of isolated $C$. perfringens showed high sensitivity to amoxicillin, ampiclox, ampicillin, pencillin and cefadroxyl. These results are in agreement with a previous results showed that $C$. perfringens were highly sensitive to ampicillin, cepelothin and penicillin (Park et al.,1994). More recently, $C$. perfringens strains isolated from intestine of broiler chickens were reported to be highly sensitive to penicillin (Silva et al., 2009).

All C. perfringens strains obtained in the present study were resistant to streptomycin, tetracycline, cloxacillin, erythrocin and oxytetracycline. Indeed, isolates from chickens with necrotic enteritis were reported to be completely resistant to streptomycin. (Park et al., 2015). Moreover, $C$. perfringens isolates were highly resistant to streptomycin $(100 \%)$, gentamicin $(93.8 \%)$ and neomycin (93.8\%) (Jun-Ho Kim et al., 2018).

\section{CONCULOSION}

In the current study, $C$. perfringens showed high prevalence among diseased broiler chickens with high isolation rate from intestinal sample than hepatic samples. Apparently healthy broiler harbored toxigenic $C$. perfringens and should be considered a potential source of dissemination and spreading of the microorganism to the environment. High percentage of $C$. perfringens were toxigenic type A in case of diseased or apparently healthy broiler chickens. $C$. perfringens virulence genes varies from locality to another with the net $\mathrm{B}$ gene seems to be unnecessary for inducing necrotic enteritis in broiler chickens.

\section{ACKNOWLEDGMENT}

The authors thank the members of the Animal Health Research Institute, Dokki Giza, Egypt for their technical support during the working and analysis of the samples.

\section{REFERENCES}

1. Abdel- Salam, W. M., 2000. 'Microbiological studies on anaerobic microorganisms causing diseases in poultry. M. V. Sc. Thesis, microbiology Fac. Vet. Med., Cairo University.

2. Abd-El-Tawab, A.A., 2002. Prevalence of clostridial microorganisms in ducks and geese. J. Egyptian Vet. Med. Ass.62, 45-57.

3. Ahmed A. and abd el- latif, M., 2004. Some studies on clostridia in the balady chickens in Dakahlia province. Ass. Vet. med. J. 50,106-119.

4. Adhikari P, Kiess A, Adhikari R, Jha R, 2020. An approach to alternative strategies to control avian coccidiosis and necrotic enteritis. Journal of Applied Poultry Research. https://doi.org/10.1016/j.japr.2019.11.005

5. Alejandro, P., James, L.S., Robert, F., Dovid, W.H. and Cerol, W.M., 2006.Analysis of care housekeeping and virulence genes reveals cryptic line ages of c.perfringens that are associated with distraction disease presentation. Genetics, A. Prm, 172, 2081-2092. 
6. Amal Nader, E., 2012. Studies on clostridium perfringens in laying hens, M. V. Sc. thesis (Microbiology), Faculty of Veterinary medicine Cairo University.

7. Anthony, L.K., XU-Xia, Y., Trudi, L.B,Filip,V., Julian, I.R. and Robert, J.M.,2010. Association between avian necrotic enteritis and Clostridium perfringens strains expressing Net B toxin .Vet .Res. 41,21.

8. Archambanlt, 2009. Bacteriophages as an alternative to antibiotics for the control of necrotic enteritis can, Poult, Mag. $2,1-5$

9. Carter, G.R. and Cole, J.R., 1990. Textbook of Diagnostic procedure in veterinary bacteriology and mycology, $5^{\text {th }}$. Ed., Academic press., Harcourt.Boace, publishers, New York, Boston, Toronto.

10. Chalmers, G.,martin,S.W.,Hunter, D.B., Prescott, J.F., Weber, L.J.and Boerlin P., 2008 Genetic diversity of Clostridium perfringens isolated from healthy broiler chickens at a commercial farm, Vet. Microbial 127,116-127.

11. Cooper,K.K., Songer, J.G., 2009. Necrotic enteritis in chickens.araradigm of anaerobe $15,55-60$

12. Das, B. C.,Dutta ,G.N. and phukan, 2001. Necrotic enteritis among fowls in Assam. Indian comp. microbiol, immunol infect. Dis. 22, 82-83.

13. Diego, paiva and Andrey M.C.Elroy, 2014. the journal of Applied poultry Research, volume 23,557-566.

14. Drew, M.D., Syed, N.A., Goldade, B.G., Laarveld, B. and Kessel, A.G.V., 2004 . Effects of dietary protein source and level on intestinal populations of Clostridium perfringens in broiler chickens. Poultry Science, 83, 414-420.

15. Ehab, A.M.R., 2007. Further studies for diagnosis of some economically important bacterial poultry disease. $\mathrm{Ph}$. D. thesis (Poultry Disease) Faculty of veterinary medicine, Cairo university.

16. Hakan, K. and Hasan,B.,2005. Isolation of C.perfringens from chicken and detection of alpha toxin gene by polymerase chain reaction(PCR). Turk.K.Vet.Anim. sci; 29, 847-851.

17. Hatheway, C. L. 1990. Toxigenic clostridia. Clin. Microbiol. Rev. 3:66-98.

18. Ismail, H.K., 2002. Pathological study of necrotic enteritis in broiler chicken in mosul region Iraqi J. vet sci, 16, 79-183.

19. Johansson, A., 2006. C. perfringens the causal agent of necrotic enteritis in poultry $\mathrm{Ph}$. D thesis , Biomedical sciences, Fac. Vet Med. Swedish univ.

20. Jun-Ho Kim, Jeong-Hwa Kim, Young-Hoan Kim, KwangHyun Cho, Sang Yoon Nam,Hu-Jang Lee and Beom Jun Lee, 2018. Antibiotic susceptibility of Clostridium perfringens type $\mathrm{D}$ isolated from feces of goats. Journal of the Preventive Veterinary Medicine. 42, 148-156.

21. Keyburn, A.L., Boyce, J.D., Vaz, P., Bannam, T.L. and Ford, M.E., 2008. NetB, a new toxin that is associated with avian necrotic enteritis caused by Clostridium perfringens. PLoS Pathog. 4, 26.

22. Keyburn, A.L., Sheedy, S.A., Ford, M.E., Williamson, M.M., Awad, M.M., Rood, J.I. and Moore, R.J., 2006. Alphatoxin of Clostridium perfringens is not an essential virulence factor in necrotic enteritis in chickens. Infect Immun.74, 64966500

23. Keyburn, A.L., Yan, X.X., Bannam, T.L., VanImmerseel, F., Rood, J.I. and Moore, R.J., 2010. Association between avian necrotic enteritis and Clostridium perfringens strains expressing NetB toxin. Veterinary Research, 41, 21.

24. Koneman, E.W., Allen, S.D., Janda, W.M., Schreckenberger, P.C. and Winn, W.C., 1992. Color atlas and textbook of diagnostic microbiology. 4th edn., J.B. Lippincott Company, Philadelphia, $\mathrm{Pa}$ Latino Vic, 1983. "Study of the characteristic of clostridium perferinge strains isolated from broilers with enteritis. Veterinaria yugosla, 32, 267-275.

25. Lovland, A. and kald, husdal M., 2001. Severely impaired production performance in broiler flocks with high incidence of $C$. perfringens associated hepatitis Avian Pathol., 30,73-81.

26. Macfaddin, J.F.,2000. Biochemical test for identification of medical bacteria 3rd edn., LippinCott Willians \& wilkins, Philadelphia, $\mathrm{Pa}$

27. NCCLS,(National Committee for Clinical Laboratory Standards) 2002. Performance standards for antimicrobial disk and dilution susceptibility tests for bacterial isolates from animals. Second Edition Approved Standards. NCCLS document M31-A2, PA 19087-19098

28. NCCLS,(National Committee for Clinical Laboratory Standards) 2004. Methods for antimicrobial susceptibility testing of anaerobic bacteria. Fifth Edition. Approved Standard M11-A6.P.A. 17.

29. Park, V.Y., Jung, S.D.,Yeh, J.G. and Seo, I.B.,1994. Studies on the necrotic enteritis of chickens in Korea, Korean J. Vet Res., 34(3):593-599.

30. Park, J.Y., Kim, S., Oh, J.Y., Kim, H.R., Jang, I., Lee, H.S. and Kwon, Y.K.,2015. Characterization of Clostridium perfringens isolates obtained from 2010 to 2012 from chickens with necrotic enteritis in Korea. Poult. Sci. 94, 1158-1164.

31. Quinn, P.J., Markey, B.K., Carter, M.E., Donnelly, W. J. Leonard, F.C. and Maguire, D., 2002. Veterinary Microbiology and Microbial Disease 2th Ed., BlackWell Science. Pp. 84-96.

32. Sambrook, J., Fritscgh, E.F., Mentiates,1989. Molecular coloning. A laboratory manual. Vol 1, Cold spring Harbor Laboratory press, New York.

33. SaraKbi, T., 1991."Necrotic enteritis strikes broiler in Yemen" Misset world poultry, 7,37.

34. Shane, S.M., koetting, D.G. and Harrington, K.S., 1984. The occurrence of clostridium perfringens in the intestine of chicks Avian dis, 28, 1120-1124.

35. Silva, R.O.S.,Salvarani, F.M., Assis, R.A., Martins, N.R.S., Pires, P.S. and Lobato, F.C.F.,2009. Antimicrobial susceptibility of clostridium perfringens strain isolated from broiler chicken .Braz.J.Microbiol,40, 261-263.

36. Smyth, J.A. and Martin, T.G., 2010. Disease producing capability of netB positive isolates of $\mathrm{C}$. perfringens recovered from normal chickens and a cow, and netB positive and negative isolates from chickens with necrotic enteritis. Veterinary Microbiology, 146, 76-84.

37. Stanley, D., Wu, S.B., Rodgers, N., Swick, R.A. and Moore, R.J., 2014. Differential responses of cecal microbiota to fishmeal, Eimeria and Clostridium perfringens in a necrotic enteritis challenge model in chickens. PLoS ONE, 9, 104739.

38. Timberment,L.,Haesebrouck,F.,Ducatella,R.and Immerseel, 2011. Necrotic enteritis in broiler .An updated Rev.on the pathogenesis. Avian pathol.40, 341-347.

39. Tschir de wahn, B., Notermans, S., warnars, K. and untermann, E .,1992."The presence of enter toxigenic clostridium perf strain in feces of various, animals" Tent, J. food microbial, 14, 165-178.

40. Van,Immerseel,F.,Buck,J.D.,Pasmenss, F. , Hunghebaest, G., Hesebrouk, Faud and Ducatelle,R., 2004. Clostridium perfringens in poultry, An emerging threat for animal and public health Avian path.33,537-549.

41. Vijay Daraira, j. and Clerk, D. 2007.Center of excellence for poultry science university of Arkansus and published in avian advice newsietter summer. volume 9, 2 .

42. Yoo, H.S., Lee, S.U., Park, K.Y. and park, Y.H., 1997. Molecular typing and epidemiological survey of prevalence of C. perfringens types by multiplex PCR. J. Clin. Microbiol., 35, 228-232 